\title{
Planning from the Margin-The European Union's Potential Role in Spatial Planning for Managing Activities in the Marine Arctic
}

\author{
David Langlet \\ Professor of Ocean Governance Law, Department of Law, School of Business, \\ Economics and Law, University of Gothenburg, Sweden
}

\begin{abstract}
The Arctic is subject to increasing levels of human activities and environmental stresses. The need to protect Arctic ecosystems and utilize the region's resources sustainably necessitates effective and coordinated management of human activities. A potentially important instrument is marine spatial planning (MSP). The article analyses the potential of the European Union (EU) to contribute to the development and implementation of MSP, or related instruments, in the marine Arctic. Although we conclude that EU law relevant to MSP currently has very limited applicability in the region, either directly or through the so-called EEA EFTA States, there are still ways in which the EU may contribute to making activities in the marine Arctic more sustainable. In this context, the EU's new 'policy for the Arctic' could be an important instrument, but it will not by itself affect the region's development or even guarantee concerted action by the EU Member States.
\end{abstract}

\section{Keywords}

marine spatial planning (MSP) - EU policy for the Arctic - Agreement on the European Economic Area (EEA Agreement) - EU jurisdiction - Arctic governance

\section{Introduction}

Even if the expected natural resources bonanza hasn't quite materialized, the Arctic is subject to ever-growing attention and increasing levels of human 
activities, including shipping, tourism and fishing. ${ }^{1}$ Arctic ecosystems are already experiencing significant change, which is likely to accelerate as a consequence not least of climate change. There is a high level of uncertainty regarding the effects of many stressors on Arctic ecosystems. This is due, inter alia, to the complexity of these systems but also to a lack of marine ecological knowledge, which for the Arctic Ocean has been described as 'staggering.'

Although change is inevitable, the extent to which it will entail degradation of ecosystems and even result in the loss of core species and important ecosystem functions will likely depend on our ability to manage human activities in the Arctic and mitigate the stressors to which these ecosystems are subjected. To be effective and efficient in terms of rational resource utilization and preservation, regulation and other policy action aimed at ameliorating the negative effects on Arctic ecosystems need to be coordinated across spatially relevant scales.

Although large parts of the Arctic Ocean, including the Central Arctic Ocean, constitute 'areas beyond national jurisdiction,, ${ }^{3}$ most of the marine Arctic, if defined as waters north of $60^{\circ} \mathrm{N}$, is in fact covered by the exclusive economic zones (EEZ) of the coastal States. This includes most of the Barents Sea, the Bering Sea, the Norwegian Sea, and the Greenland Sea. Fishing in these areas is hence under the legal control of the relevant coastal State. The same goes for, e.g., oil and gas exploitation and other use of natural resources. ${ }^{4}$

A main instrument, or procedure, for managing in an integrated way human activities that make use of and affect ocean resources, including ocean space, is marine (or maritime) spatial planning (MSP). ${ }^{5}$ In line with the overall theme of this issue, i.e., the EU's role in the Arctic, this article analyses the potential of the EU to contribute to the development and implementation of MSP, or related instruments, in the Arctic region for the benefit of Arctic ecosystems and the sustainable and rational utilization of the region's resources.

1 Pame, The Arctic Ocean Review Project, Final Report (Phase II 2011-2013) (Kiruna, May 2013) 18-19; J N Larsen and G Fondahl, Arctic Human Development Report Regional Processes and Global Linkages (Nordic Council of Ministers 2014, TemaNord 2014:567 (AHDR II, 2014) 33.

2 P Wassermann, 'Overarching perspectives of contemporary and future ecosystems in the Arctic Ocean' (2015) 139 Progress in Oceanography 1-12, at p.1, DOI:10.1016/j.pocean.2015.08.004.

3 See further, E J Molenaar, 'Status and Reform of International Arctic Fisheries Law' in E Tedsen, S Cavalieri and R Kraemer (eds), Arctic Marine Governance: Opportunities for Transatlantic Cooperation (Springer, Berlin, 2014) 103-125, at p. 105.

4 United Nations Convention on the Law of the Sea (LOSC). Adopted 10 December 1982, Montego Bay; in force 16 November 1994, 1833 UNTS 397, Art. 56.

5 In the following 'marine spatial planning' is used in this text because 'maritime' may (but not necessarily does) imply a focus on shipping and related activities. 
After briefly discussing MSP as a concept, we introduce the Arctic Council and its role in relation to MSP. Thereafter we turn to the $\mathrm{EU}$ and its relation to the marine Arctic. Three pieces of EU law particularly pertinent to MSP are discussed, as is the potential for their application in the marine Arctic. In addition to applying EU law ratione loci, i.e., based on jurisdiction over a specific area, the potential for applying relevant EU law ratione personae is also analyzed as is, briefly, the utility of measures based on port state jurisdiction. Finally, some conclusions are drawn regarding how and to what extent the EU can apply or influence the development of MSP and other regulatory instruments relevant for the protection and sustainable utilization of the marine Arctic.

\section{Marine Spatial Planning}

Although MSP is not the only tool for sea-use management, it is perhaps the most comprehensive and the one that has gained most traction for dealing with large-scale ocean management challenges. ${ }^{6}$ MSP has been described as 'a public process of analysing and allocating the spatial and temporal distribution of human activities in marine areas to achieve ecological, economic, and social objectives that usually have been specified through a political process. ${ }^{7}$ Importantly, MSP is an iterative process which has adaptation due to changing circumstances and increasing understanding of the effects of management measures as an intrinsic property. At the heart of the MSP concept is also the recognition that general single-sector management approaches have often failed to achieve sustainable practices and that management should rather be integrative and area-focused.

There is no international legal framework explicitly regulating or prescribing MSP. Even though large parts of the United Nations Convention on the Law of the Sea (LOSC) $)^{8}$ and the system of jurisdictional zones that it establishes may be seen as a basic form of spatial planning for marine areas, these rules are primarily focused on allocating competences and only in very general terms provide for integrative management or the coordination of plans and

6 On other tools for ecosystem-based, sea-use management, see C Ehler and F Douvere, Visions for a Sea Change. Report of the First International Workshop on Marine Spatial Planning', IOC Manual and Guides No. 48 (Intergovernmental Oceanographic Commission and Man and the Biosphere Programme, unesco, 2006) 24.

7 Unesco Marine Spatial Planning Initiative at http://www.unesco-ioc-marinesp.be/; accessed 18 September 2016.

$8 \operatorname{LosC}\left(\mathrm{n}_{4}\right)$. 
activities needed for transboundary MSP. ${ }^{9}$ However, MSP is often perceived as a tool for implementing the ecosystem approach, ${ }^{10}$ as endorsed by the Conference of the Parties to the Convention on Biological Diversity (СвD $)^{11}$ in 1995 when establishing that this approach should be the primary framework of action to be taken under the Convention. ${ }^{12}$ The meaning of 'ecosystem approach' was later elaborated in the so-called Malawi Principles, ${ }^{13}$ which emphasize, inter alia, that management must be undertaken at the appropriate scale, that it must be based on the recognition that change is inevitable, that all relevant sectors should be involved in biodiversity management, and that an appropriate balance between conservation and use of biodiversity should be sought. As discussed below, there are also some international initiatives regarding MSP, or MSP-related concepts, specifically focusing on the Arctic.

\section{The Arctic Council}

The main forum for coordinating State action with respect to the Arctic is the Arctic Council, which has as members the eight countries whose territories fall to some extent within the Arctic (according to the definition used within the Arctic Council), ${ }^{14}$ i.e., Canada, Denmark (through Greenland and the Faroe Islands), Finland, Iceland, Norway, Russia, Sweden, and the United States. Out of these eight, three are Eu Member States, i.e., Denmark, Finland and Sweden, and two, Iceland and Norway, are members of the European Economic Area (EEA) and thus closely associated with the EU. An additional seven EU Member States have been granted observer status in the Council. The EU itself has not yet been formally granted such status but may nonetheless observe the

9 On the role of the LOsC for marine spatial planning, see D Hassan and N Soininen 'United Nations Convention on the Law of the Sea as a Framework for Marine Spatial Planning' in D Hassan, T Kuokkanen and N Soininen (eds), Transboundary Marine Spatial Planning and International Law (Routledge, London, 2015) 60-84.

10 See, e.g., F Maes, 'The international legal framework for marine spatial planning' (2008) 32 Marine Policy 797-810; DOI: 10.1016/j.marpol.2008.03.013.

11 Convention on Biological Diversity (СвD). Adopted 5 June 1992, Rio de Janeiro; in force 29 December 1993, 1760 UNTS 79.

12 Decision II/8, Report of the 2nd Meeting, 6-17 November 1995, UNEP/CBD/COP/2/19, Annex II (30 November 1995).

13 Submission by the Governments of the Netherlands and Malawi, Report of the Workshop on the Ecosystem Approach, 28 January 1998, UNEP/CBD/COP/4/Inf.9, 7.

14 N Einarsson, J Nymand Larsen, A Nilsson, and OR Young, Arctic Human Development Report 2004 (Akureyri: Stefansson Arctic Institute, 2002) ('AHDR I, 2002') 17-18. 
proceedings of the Arctic Council on the same terms as other observers and is de facto contributing to its work..$^{15}$

Whereas the Arctic Council has not engaged to any significant extent with MSP as such, the significance of ecosystem-based management (Евм) has been emphasized in the Council's work. In its first Arctic Marine Strategic Plan, the Working Group on Protection of the Arctic Marine Environment (PAME) identified ввм as the best approach to managing the Arctic marine environment in such a way as to conserve Arctic marine biodiversity and ecosystem functions and to advance sustainable Arctic marine resource use. ${ }^{16}$ The second Strategic Plan, adopted in 2015, describes Евм as 'a cornerstone of the work of the Arctic Council and an important principle to the Arctic States'. ${ }^{17}$ According to the principles of ЕВM set out in the plan, Евм is place-based, with geographic areas defined by ecological criteria, and may require efforts at a range of spatial and temporal scales. It also aims to understand and address the cumulative impacts of multiple human activities, rather than individual sectors, species or ecosystem components. ${ }^{18}$

It should also be mentioned that the Arctic Council's Conservation of Arctic Flora and Fauna working group (CAFF) has called for a move to more flexible, adaptable wildlife and habitat management, including MSP approaches, which are seen as having the potential to respond effectively to rapid changes in Arctic biodiversity. ${ }^{19}$

15 A Stępień and T Koivurova, 'The Making of a Coherent Arctic Policy for the European Union: Anxieties, Contradictions and Possible Future Pathways' in A Stępień, T Koivurova and P Kankaanpää (eds), The Changing Arctic and the European Union (Brill Nijhoff, Leiden, 2016) 36 .

16 Arctic Council, Arctic Marine Strategic Plan, 24 November 2004, PAME International Secretariat. Available at https://pame.is/images/o1_PAME/AMSP/AMSP_Nov_2004.pd; accessed 5 September 2017, 3 and 8.

17 Arctic Council, Arctic Marine Strategic Plan 2015-2025 - Protecting Marine and Coastal Ecosystems in a Changing Arctic, April 2015, PAME International Secretariat. Available at https://pame.is/index.php/projects/arctic-marine-strategic-plan-2015-2025; accessed 5 September 2017, 10.

18 Ibid., at p. 9.

19 J Eamer, G M Donaldson, A J Gaston, K N Kosobokova, K F Lárusson, I A Melnikov, J D Reist, E Richardson, L Staples, CH von Quillfeldt, Life Linked to Ice: A Guide to SeaIce-Associated Biodiversity in This Time of Rapid Change. CAFF Assessment Series No. 10. Conservation of Arctic Flora and Fauna, 2013. Available at http://www.caff.is/sea-ice -associated-biodiversity; accessed 12 April 2017. 


\section{The Role of the European Union}

In April 2016 the EU Commission and the EU High Representative for Foreign Affairs and Security issued a much-awaited document called 'an integrated European Union policy for the Arctic.' ${ }^{20}$ It 'sets out the case' for an EU policy focusing on advancing international cooperation in response to the impacts of climate change on the Arctic's fragile environment, and promoting and contributing to sustainable development, particularly in the European part of the Arctic. ${ }^{21}$ However, the document does not necessarily reflect a coherent view among the EU's Member States, or other parts of the EU. ${ }^{22}$ Also, it is characterized more by listing and confirming various existing activities and projects than by introducing any striking novelties in terms of measures to be taken by the EU. However, at least as regards legal action, this is not too surprising considering the overall position of the $\mathrm{EU}$ in relation to the Arctic.

As noted above, there are only three EU Member States whose territories are partly located within the Arctic area: Denmark, Finland and Sweden. Denmark is a special case, because those parts of the Kingdom of Denmark that are in the Arctic, i.e., Greenland and the Faroe Islands, are not included in Denmark's membership of the EU. Greenland left the then EEC after a referendum in 1982.

Through Finland and Sweden there is EU territory in the Arctic. But, as has often been pointed out, the EU does not have any Arctic coast, and hence no EEZ or continental shelf in the Arctic. This means that EU law is not applicable ratione loci in any marine Arctic areas. But as Iceland and Norway are members of the EEA, EU law could still apply indirectly through these States. It

20 Joint communication to the European Parliament and Council: An integrated European Union policy for the Arctic (27 April 2016) JOIN(2016) 21 final.

21 Ibid., at p. 2. The Council of the European Union has confirmed that the thematic and geographical focus and policy responses outlined in the Joint Communication rightly place the emphasis on sustainable development and use of the Arctic while safeguarding its delicate environment and important ecosystems'. The Council also 'encourages close cooperation between EU institutions and Member States in the context of Arctic challenges'. Council of the European Union, Council Conclusions on the Arctic, 20 June 2016, 10172/1/16 REV 1, paras. 5 and 11.

22 On the relationship between Arctic policy making at the Eu level and the action of the Member States on Arctic matters, as well as differences between EU institutions in the formulation of Arctic policy, see A Stępien, 'Internal Contradictions and External Anxieties: One "Coherent" Arctic Policy for the European Union' (2015) 7 Yearbook of Polar Law 249-289, DOI: 10.1163/2211-6427_011. 
should be noted that the EEA Agreement does not apply to Svalbard, ${ }^{23}$ the exercise of Norwegian sovereignty over which is somewhat restricted by the 1925 Svalbard Treaty. ${ }^{24}$

The EEA Agreement, which essentially joins the EU Member States and the three EEA EFTA States, Iceland, Liechtenstein, and Norway, in a single market ${ }^{25}$ is a hybrid between a traditional intergovernmental agreement and the supranationality of EU law. EFTA States have not transferred any power of decision to EEA joint institutions. Instead, decisions are made by consensus. Meanwhile, there are certain principles in the Agreement that in case of conflict give EEA rules, at least in principle, priority over national rules in EFTA States. ${ }^{26}$ The EEA Agreement covers, inter alia, free movement of goods, with the important exception of fish and agricultural goods, and cooperation on environmental protection. EU legal acts adopted after the entry into force of the EEA Agreement become part of EEA law through a unanimous decision by the EEA Committee, which is composed of representatives of the EEA EFTA States and the European External Action Service.

A number of EU legal acts could be of relevance for spatial and environmental governance of at least significant parts of the European Arctic through these EEA States. The three most important pieces of EU law in this regard are further discussed here, as is the position of the concerned EFTA EEA States with regard to the applicability of that EU law.

23 Lov om gjennomføring i norsk rett av hoveddelen i avtale om Det europeiske økonomiske samarbeidsområde (Eøs) m.v., LOV-1992-11-27-109 (Eøs-loven) (Law on implementation in Norwegian law of the main part in the Agreement on the European Economic Area (EEA) etc.) $§ 6$.

24 The Svalbard Treaty. Adopted 9 February 1920, Paris; in force 14 August 1925, 2 LNTS 7 (also known as Treaty Concerning the Archipelago of Spitsbergen).

25 The European Free Trade Association (EFTA) has four Member States: Iceland, Liechtenstein, Norway, and Switzerland, but Switzerland is not a member of the EEA.

26 Agreement on the European Economic Area. Adopted 17 March 1993, Brussels; in force 1 January 1994, [1994] OJ L1/3 (EEA Agreement), Arts. 6 and 7 and Protocol 35 on the implementation of EEA rules. See further HP Graver, 'Mission Impossible: Supranationality and National Legal Autonomy in the EEA Agreement' (2002) 7 European Foreign Affairs Review 73-90. 


\section{Pertinent EU Law and Policy}

\section{The Maritime Spatial Planning Directive}

Most important for the purpose of the present analysis is clearly the EU's MSP legislation, i.e., Directive 2014/89/EU establishing a framework for maritime spatial planning, which aims to promote the sustainable growth of maritime economies, the sustainable development of marine areas and the sustainable use of marine resources. ${ }^{27}$ It requires Member States to set up maritime spatial plans identifying the spatial and temporal distribution of relevant existing and future activities and uses. ${ }^{28}$ The development of the plans must ensure transboundary cooperation between Member States and also promote cooperation with third countries. ${ }^{29}$

The Directive is generally deferent to national policies and priorities and rather than introducing new sectoral policy targets the plans should reflect, integrate and link the objectives defined by national or regional sectoral policies. The proposal for a directive on MSP initially tabled by the EU Commission was more strongly worded with respect to both cooperation among Member States and cooperation with third countries, but those provisions met with strong opposition and were watered down in the legislative process. ${ }^{30}$

Important to the present analysis is that the Directive has not been identified by the Eu legislator as a piece of legislation that should be incorporated in the EEA agreement. The Directive has four legal bases, i.e., Treaty provisions, primarily in the Treaty on the Functioning of the European Union (TFEU), ${ }^{31}$ which define the Eu's competence to take measures within a particular policy area. Among them is the basis for the common fisheries policy, ${ }^{32}$ i.e., an area explicitly excluded from the scope of the EEA and also an area where both Iceland and Norway are strongly resisting EU influence. Indeed, control

27 Directive 2014/89/EU establishing a framework for maritime spatial planning [2014] OJ L257/135, Art. 1 .

28 Ibid., Art. 8.

29 Ibid., Art. 6.

30 Compare ibid. Arts. 11 and 12 with Arts. 12 and 13 of Proposal for a Directive of the European Parliament and of the Council establishing a framework for maritime spatial planning and integrated coastal management (12 March 2013) сом(2013) 133 final. See also A Zervaki, 'The Legalization of Maritime Spatial Planning in the European Union and Its Implications for Maritime Governance' (2016) 30 Ocean Yearbook 32-52.

31 Consolidated version of the Treaty on the Functioning of the European Union [2012] oj $\mathrm{C}_{326 / 47}$.

32 I.e., Art. 43(2) TFEU. The other legal bases are Art. 100(2) on sea and air transport, Art. 192(1) on environment, and Art. 194(2) on energy. 
over fisheries was among the key issues behind the Norwegian and Icelandic decisions to remain outside the EU. ${ }^{33}$ There thus seems to be little prospect of the Directive becoming part of the EEA Agreement and applicable to the EEA EFTA States, even though the Directive, due to the deference paid to national policies and priorities hardly impinges on States' ability to manage their fisheries resources.

\section{The Marine Strategy Framework Directive}

Directive 2008/56/EC establishing a framework for community action in the field of marine environmental policy aims to ensure the integration of environmental concerns into policies, agreements, and legislative measures which have an impact on the marine environment. ${ }^{34}$ Within the framework established by the Directive, the Member States are obliged, subject to some exceptions, ${ }^{35}$ to take the necessary measures to achieve or maintain 'good environmental status' in the marine environment by 2020 at the latest. ${ }^{36}$ This is to be done through the development and implementation of marine strategies by each Member State. ${ }^{37}$ With respect to shared marine regions, one of which is the North-east Atlantic Ocean, ${ }^{38}$ the Member States concerned shall cooperate to ensure that the measures required to achieve the objectives of the Directive are coherent and coordinated. ${ }^{39}$

In 2011, the Norwegian Government decided that the Directive was not to be incorporated into the EEA Agreement. In its view the Directive applies largely to areas outside the geographical scope of the Agreement by including the EEZ and the continental shelf, whereas the EEA Agreement, according to its Article 126 , 'shall apply to the territories' of, inter alia, Iceland and Norway. ${ }^{40}$ 'Territory' is generally understood to include the land territory and the territorial sea but not the EEZ or continental shelf. However, the EU Court of Justice has repeatedly extended the reach of Eu law to include activities on the shelf

33 Stępień and Koivurova ( $\mathrm{n}$ 15) 34-35.

34 Directive 2008/56/EC of the European Parliament and of the Council of 17 June 2008 establishing a framework for community action in the field of marine environmental policy (Marine Strategy Framework Directive) [2008] oJ L164/19, Art. 1.

35 Ibid., Art. 14.

36 Ibid., Art. 3.

37 Ibid., Art. 1.

38 Ibid., Art. 4.

39 Ibid., Art. 8.

$40 \quad$ Norwegian Ministry of Foreign Affairs, 'The EEA Agreement and Norway's other agreements with the EU', Meld. St. 5 (2012-2013) Report to the Storting (White Paper) 14; Agreement on the European Economic Area (n 26), Art. 126. 
or in the EEZ in cases where that does not follow explicitly from any relevant piece of EU law. ${ }^{41}$ It is not unlikely that the EFTA Court, which tends to be strongly influenced by the case law of the Eu Court of Justice, would decide similarly were it to be presented with the issue. ${ }^{42}$ Among Norwegian legal scholars it is rather an open question whether EEA law in fact applies beyond the territorial sea. ${ }^{43}$ Whether the Norwegian Government's position is the legally correct one remains an open issue.

\section{The Offshore Directive}

Directive 2013/30/EU on safety of offshore oil and gas operations is based on the recognition that the risks relating to major offshore oil or gas accidents are significant and that such accidents are likely to have devastating and irreversible consequences on the marine and coastal environment. ${ }^{44}$ It establishes minimum requirements for preventing major accidents in offshore oil and gas operations and limiting the consequences of such accidents. The Directive includes a number of general principles, including that operators shall be required to take all suitable measures to prevent major accidents and that they may not be relieved of their duties by the fact that actions or omissions contributing to major accidents were carried out by contractors. ${ }^{45}$

The Directive applies to activities in the territorial sea, the EEZ, and the continental shelf of EU Member States. ${ }^{46}$ Operators and owners registered in the

41 The Eu Court of Justice has, inter alia, held that 'work carried out on fixed or floating installations positioned on the continental shelf, in the context of the prospecting and/ or exploitation of natural resources, is to be regarded as work carried out in the territory of [the Member State] for the purposes of applying EU law ...' C-347/10 Salemink ECLI:EU:C:2012:17. On the application of environmental law in the EEZ, see Case C-6/04 Commission v United Kingdom ECLI:EU:C:2005:626 and D Langlet and S Mahmoudi, EU Environmental Law and Policy (Oxford University Press, Oxford, 2016) 36-40.

On the relationship between the two courts, see H Haukeland Fredriksen, 'The EEA and the case-law of the ECJ: Incorporation without participation?' in EO Eriksen and JE Fossum (eds), The European Union's Non-Members: Independence under hegemony? (Routledge, Abingdon, 2015) 102-117.

43 F Arnesen, 'The EEA Agreement and activities off-shore, (2011) 400 MarIus 19-26; H H Fredriksen, EU/EØS-rett i norske domstoler (Utvalget for utredning av Norges avtaler med EU, 2011) 66-68. The author is indebted to Professor Erik Røsæg, University of Oslo, for valuable comments regarding the geographical application of the EEA Agreement. Directive 2013/30/EU of the European Parliament and of the Council of 12 June 2013 on safety of offshore oil and gas operations and amending Directive 2004/35/EC [2013] OJ L178/66, preambular paras 4 and 6 .

46 Ibid., Art. 1(1) and the definition of 'offshore' in Art. 2(2). 
territory of a Member State should also be 'expected' to apply, as far as possible, the same corporate major accident prevention policy when operating outside offshore waters of Member States as they do when operating in these waters. ${ }^{47}$

The Offshore Directive, which is part of the EU's environmental policy, ${ }^{48}$ has been indicated by the EU legislator as of 'EEA relevance', i.e., a legal act that should be included in the EEA Agreement. However, both Iceland and Norway have rejected its applicability to the EEA EFTA States. This is due, inter alia, to the Directive's geographical scope, i.e., the fact that it applies to the EEZ and the continental shelf in addition to the territorial sea. ${ }^{49}$ There are also differing interpretations regarding the substantive obligations that follow from the EEA Agreement. ${ }^{50}$ However, even if the Offshore Directive were to be implemented by the EEA EFTA States, that would be unlikely to significantly enhance the spatial or temporal planning or coordination of marine activities in the Arctic, as that is not the Directive's focus.

\section{Marine Spatial Planning in the European Arctic beyond European Union Law}

As seen above, the direct impact on the marine Arctic of EU law pertaining to MSP or related policies, either as such or through the EEA Agreement, is quite limited. However, this does not mean that there is no MSP happening in the European Arctic. In fact, MSP has been in place in Norway for some years, although not as a result of it being required by the EEA Agreement but as a national initiative. In 2006, the Norwegian Parliament approved an integrated management plan, including spatial and temporal management measures,

$47 \quad$ Ibid., preambular para. 37.

48 It has Art. 192 TFEU, i.e., the EU's environmental policy, as its legal basis.

49 C Cinelli, 'Law of the Sea, the European Union Arctic Policy and Corporate Ocean Responsibility' (2016) 30 Ocean Yearbook 242-266, DOI: 10.1163/22116001-03001010, at p. 252; Stępień and Koivurova (n 15) at pp. 34-35.

5o In the EEA Agreement, the chapter on 'Environment' is included in the part on 'Horizontal provisions relevant to the four freedoms' which opens for discussion the extent to which a link to the four freedoms - and the nature of such a link - must be established with respect to each EU legal act pertaining to the environment for it to be considered EEArelevant. On the notion of 'EEA-relevant' and its interpretation, see F Sejersted, F Arnesen, O-A Rognstad, S Foyn, O Kolstad, EØS-rett (3rd ed., Universitetsforlaget, Oslo, 2011) 187-191 (in Norwegian). 
for the Norwegian part of the Barents Sea and the sea areas off the Lofoten Islands. ${ }^{51}$ The Barents Sea plan was revised in 2010. The plan integrates previously separate management regimes and addresses all important economic sectors, including fisheries, shipping, oil and gas, and nature conservation. In 2010, the Norwegian Parliament also approved an integrated management plan for the Norwegian Sea. ${ }^{52}$ The plans are not based on planning legislation, but elaborated by sector authorities and the relevant stakeholders. ${ }^{53}$

Although less advanced in the field of MSP, Greenland has pilot projects for MSP under way, ${ }^{54}$ and Iceland is in the process of developing a framework for MSP. ${ }^{55}$

\section{The European Union's Influence beyond Jurisdiction Ratione Loci}

Even if Eu law relevant to marine resource management currently has little applicability ratione loci to marine areas in the Arctic, there may still be ways in which the EU can regulate or at least influence activities in such areas. It may be either by applying Eu law in other ways, or by influencing the development and application of other rules and policies applicable in the region.

As for the application of EU law, there is the possibility of application ratione personae rather than ratione loci, i.e., based on the nationality of the actor rather than the place of the action. Public international law allows for

$5^{1}$ On this plan, see The Royal Norwegian Ministry of the Environment, 'Integrated Management of the Marine Environment of the Barents Sea and the Sea Areas off the Lofoten Islands' (Report No. 8 to the Storting, 2005-2006) available at http://www.miljo direktoratet.no/Global/Havforum/Report\%2oNo\%208\%2oto\%2othe\%2oStorting\%2o Integrated\%2oManagement $\% 200 f \% 20$ the $\% 20$ Marine $\% 20$ Environment $\% 200$ f $\% 20$

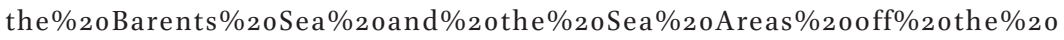
Lofoten\%2oIsland\%20(2005-2006).pdf; accessed 25 January 2018.

$5^{2}$ CN Ehler, 'Pan-Arctic Marine Spatial Planning: An Idea Whose Time Has Come' in E Tedsen, S Cavalieri and RA Kraemer (eds), Arctic Marine Governance: Opportunities for trans-Atlantic Cooperation (Springer, Heidelberg, 2013) 199-213, at p. 200; and Marine Spatial Planning Initiative, 'Barents Sea-Lofoten' at http://www.unesco-ioc-marinesp.be/ MSP_around_the_world/norway_barents_sea; accessed 23 September 2016.

53 Results of the 2nd Nordic Workshop on Marine Spatial Planning and an up-date for 2014: Use and Management of Nordic Marine Areas: Today and Tomorrow (Reykjavik, Iceland, 12-13 November 2013) 12-13. Available at http://www.mspchallenge.info/ uploads/3/1/4/5/31454677/fulltexto1.pdf; accessed 16 June 2017.

$54 \quad$ Ibid., at p. 8.

55 Ibid., at p. 11. 
the EU to regulate activities by nationals of Member States, as well as activities on board ships flying the flag of such a State on the High Seas or in the EEz of a third State, as long as the measures are consistent with the jurisdictional rules of the law of the sea. As for the internal EU perspective, the Court of Justice of the EU has found that the EU has the same possibility to legislate in respect of matters falling within its competence as a Member State has as flag State. ${ }^{56}$

The rules of the Eu's Common Fisheries Policy pertaining to the conservation of marine biological resources and the management of fisheries and fleets exploiting such resources apply in principle not only to EU waters but generally to EU fishing vessels outside those waters and to nationals of EU Member States, without prejudice to the primary responsibility of the flag State. ${ }^{57}$ There is hence room for the $\mathrm{EU}$ to require sustainable fishing practices by $\mathrm{EU}$ vessels and nationals in the Arctic. The effects of unilateral EU measures may be limited, but if the EU can demonstrate that its measures are effective and possibly also profitable in the longer term, that could serve as an attractive example for other States. $^{58}$

Even activities by non-nationals or by ships not flying a Member State flag in areas beyond the Eu's jurisdiction ratione loci can fall under the purview of EU law. EU fisheries law makes use of port state jurisdiction, i.e., the competence of States to exercise prescriptive and enforcement jurisdiction over foreign vessels within their ports, ${ }^{59}$ with the aim of influencing the activities of foreign ships and nationals in such areas. One example is the Regulation on illegal, unreported and unregulated (IUU) fishing, which establishes a scheme of inspections for third-country fishing vessels calling at the ports of Member States and makes compliance with the EU's rules on IUU fishing a prerequisite for access to such ports. ${ }^{60}$ The Regulation uses this mechanism essentially to

56 Case C-405/92 Mondiet ECLI:EU:C:1993:906, para. 12.

57 Regulation (EU) No. 1380/2013 of the European Parliament and of the Council of 11 December 2013 on the Common Fisheries Policy [2013] OJ L354/22, Art. 1.

$5^{8} \quad \mathrm{~N}$ Liu and E Kirk, 'The European Union's potential contribution to protect marine biodiversity in the changing Arctic: a roadmap' (2015) 30 International Journal of Marine and Coastal Law 255-284, DOI: 10.1163/15718085-12341354, at p. 272.

59 EJ Molenaar, 'Port State Jurisdiction', Max Planck Encyclopedia of Public International Law [MPEPIL], adapted April 2014. Available at: http://opil.ouplaw.com.ezproxy.ub.gu.se/ home/epil; accessed 5 September 2017.

6 Council Regulation (EC) No. 1005/2008 of 29 September 2008 establishing a Community system to prevent, deter and eliminate illegal, unreported and unregulated fishing [2008] OJ L 286/1, Arts. 1 and 4(2). 
give effect to international agreements and policies aimed at combating IUU fishing globally. ${ }^{61}$

More innovative is the 2012 Regulation on certain measures for the purpose of the conservation of fish stocks in relation to countries allowing nonsustainable fishing. ${ }^{62}$ It provides for the adoption of sanctions, including quantitative restrictions on importation of fish and restrictions on the use of EU ports by third-country vessels or fleets. Such measures may be directed at countries, and at specific vessels or fleets of countries with an interest in a fishery involving a stock of common interest to that country and to the EU, i.e., a stock that is geographically available to both the $\mathrm{EU}$ and third countries. If such a country has allowed fisheries activities that jeopardize the sustainability of a stock of common interest and fails to cooperate with other countries and the EU in its management, measures can be instituted by a so-called implementing act adopted by the EU Commission under the supervision of a Member State committee. ${ }^{63}$ Though partly controversial, ${ }^{64}$ the Regulation shows a preparedness of the EU to try to influence non-EU actors beyond its jurisdiction $r a-$ tione loci in marine areas. Port state measures to sanction activities beyond EU waters can also be found outside fisheries policy, notably in relation to ship-source pollution. ${ }^{65}$

Denial of access to EU ports, or the taking of other measures based on port state jurisdiction, with respect to vessels or fleets that do not respect, or fly the flag of countries that do not respect, rules and standards on nature protection and natural resource management have a potential to be applied more widely and could, given the importance of EU ports to many Arctic marine operations, have a deterring effect on unsustainable practices. But although it is widely recognized that States may impose conditions for access to their

61 M Tsamenyi, MA Palma, B Milligan and K Mfodwo, "The European Council Regulation on Illegal, Unreported and Unregulated Fishing: An International Fisheries Law Perspective' (2010) 25 The International Journal of Marine and Coastal Law 5-31, at p. 18.

62 Regulation (EU) No 1026/2012 of the European Parliament and of the Council of 25 October 2012 on certain measures for the purpose of the conservation of fish stocks in relation to countries allowing non-sustainable fishing [2012] oJ L 316/34.

63 Ibid., Arts. 2-4. On the adoption of implementing acts, see further Langlet and Mahmoudi (n 41 ) at p. 24.

64 For a critique, see M Vatsov, 'The EU's failed attempt to innovate with Regulation 1026/2012' (2017) 84 Marine Policy 300-305, DO I: 10.1016/j.marpol.2017.06.029, at p. 2.

65 Directive 2005/35/EC of the European Parliament and of the Council on ship-source pollution and on the introduction of penalties for infringements [2005] oJ L 255/11, Art. 3(1)e. 
ports, ${ }^{66}$ they can only enforce measures through port state jurisdiction which they are allowed under international law to prescribe in the first place. ${ }^{67} \mathrm{~A}$ basis for prescriptive jurisdiction may exist, inter alia, if the rule that is to be enforced has a clear link to the port as such - e.g., an obligation to provide certain information regarding the vessel and its activities upon arrival at port ${ }^{68}$ - or follow from international agreements. ${ }^{69}$ Any measures taken must also be proportionate, non-discriminatory and taken in good faith, ${ }^{70}$ and may have to be assessed as to their compatibility with international trade law. ${ }^{71}$ It must also be recognized that port state jurisdiction hardly provides a basis for anything akin to MSP or more integrated marine protection along the lines of the Marine Strategy Framework Directive.

It is often held that the EU has significant clout as a major buyer of goods from the Arctic, most notably oil, gas and fish..$^{72}$ Although this argument has some merit, the policy significance of the EU as a market for Arctic goods should not be overstated. In practice, it is mainly from Norway that fish is being imported, and that fish is predominantly salmon farmed in Norway's internal waters and territorial sea. ${ }^{73}$ Furthermore, Norway is a country already closely linked to the EU and shares many of its views and objectives, even though it balks at implementing EU law on MSP and marine environmental protection. Although it constitutes a modest part of EU fish import, a large share of Icelandic fish export is destined for EU Member States, ${ }^{74}$ thus potentially giving the $\mathrm{EU}$ a certain leverage. But as noted, the imposition of trade restricting

66 S Kopela, 'Port-State Jurisdiction, Extraterritoriality, and the Protection of Global Commons' (2016) 47 Ocean Development \& International Law 89-130, DoI: 10.1080/ oogo8320.2016.1159083, at p. 94 esp. note 50 with further references; B Marten, 'Port State Jurisdiction, International Conventions, and Extraterritoriality: An Expansive Interpretation' in H Ringbom (ed), Jurisdiction over Ships: Post-UNCLOS Developments in the Law of the Sea (Brill, Leiden, 2015) 103-139, at p. 115.

67 C Ryngaert and H Ringbom, 'Introduction: Port State Jurisdiction: Challenges and Potential' (2016) 31 The International Journal of Marine and Coastal Law 379-394, Dor: $10.1163 / 15718085^{-12341405}$, at p. 383 ; Kopela (n 66) at p. 94.

68 Ryngaert and Ringbom (n 67) at p. 383; Marten (n 66) at p. 119; 128; Kopela (n 66) at p. 97.

$69 \quad$ Kopela (n 66) at p. 92.

$70 \quad$ Marten (n 66) at p. 114.

71 Ibid., at p. 122; Ryngaert and Ringbom (n 67) at p. 387.

72 See e.g. Stępień and Koivurova (n 15) at p. 24.

73 The European Market Observatory for Fisheries and Aquaculture Products (вumofa), The EU fish market (Directorate-General for Maritime Affairs and Fisheries of the European Commission, 2015) 26.

74 'Iceland' at The Observatory of Economic Complexity. Available at atlas.media.mit.edu/ en/profile/country/isl/; accessed 27 June 2017. 
measures is subject to significant legal constraints, primarily through World Trade Organization (WTO) law. One must also ask how hard it would be for Icelandic exporters to find alternative markets, were the $\mathrm{E} U$ to link unpalatable requirements to the import or consumption of Icelandic fish?

As for energy imports, two Arctic countries, Norway and Russia, together supply over half of the EU's natural gas and over 40 per cent of its oil. Russian natural gas represents such a large part of the Eu's imports that it is often described as creating an energy dependence. ${ }^{75}$ Arguably, the dependence could go both ways. However, it is common knowledge that stated EU principles and values do not currently hold great sway in Russia, despite its relative dependence on the $\mathrm{EU}$ for its gas exports.

The ability of the EU to impose its standards on others is limited by both legal and practical considerations and it may be questioned whether it is even a desirable pursuit. Using trade measures as a means to influence behaviour outside the EU may, as the experiences with the imposition of a ban on the import of certain seal products show, ${ }^{76}$ work to alienate key Arctic actors rather than to foster support for purported EU values. ${ }^{77}$

What seems like a more viable path is to continue the EU's rather significant contribution to increasing the scientific understanding of the Arctic by means of environmental monitoring and research. The EU could also potentially, provided that it is able to successfully implement its policies, including the transboundary elements of MSP 'at home', serve as a model for other States and multilateral initiatives, including the Arctic Council. Even though the EU may not be a forerunner with respect to MSP, it has, through the close cooperation between neighbouring States that is the basic premise of the EU, good prerequisites for achieving viable transboundary MSP, at least in some of the EU's marine areas.

There are also many initiatives and processes concerning the Arctic in which the EU and/or EU Member States are already much involved, such as the Northern Dimension, a joint policy between EU, Russia, Norway and

75 See further Eurostat, 'Statistical analysis of EU trade in energy products, with focus on trade with the Russian Federation'. Available at http://ec.europa.eu/eurostat/statistics -explained/index.php/Archive:Trade_in_energy_products; accessed 23 August 2017.

76 See Regulation (EC) No 1007/2009 of the European Parliament and of the Council of 16 September 2009 on trade in seal products [2009] oJ L286/36.

77 On some of the reactions by Arctic actors to the so-called seal ban, see Stępień (n 22) at p. 279 . 
Iceland, ${ }^{78}$ and the regional fisheries management organization for the NorthEast Atlantic (NEAFC). ${ }^{79}$

\section{Conclusions}

EU law relevant to MSP has currently very limited applicability in the marine Arctic. One notable exception is the ability of the Eu to apply, inter alia, fishing rules to its citizens and to vessels registered in a Member State. EU law also provides for the enforcement by means of port state jurisdiction of certain legal norms of relevance to the marine Arctic environment. Such measures could potentially be expanded, but close attention must be paid to trade law commitments and to principles of fairness and non-discrimination. Also, the effect that can reasonably be expected from such measures falls far short of influencing the spatial and temporal governance of human activities in the marine Arctic in a systematic or integrated manner.

This does not mean that the EU cannot be a relevant Arctic actor, in particular as a major funder of research and environmental monitoring. The 2016 communication on an integrated EU policy for the Arctic puts much emphasis on science as a 'catalyst to support a common understanding, enabling jointly agreed solutions to be reached and foster peaceful cooperation.'80 The EU's more tangible influence on Arctic policy making is largely dependent on the ability of the EU and the Member States to agree on and pursue common objectives. The 2016 Arctic policy communication is an important step but does in itself say little about how the various parts of the EU, including the Member States will act in different forums, including the Arctic Council.

The EU is not a member of the Arctic Council. It does, however, participate as a de facto observer. The Council has come some way towards coordinating activities aimed at protecting the Arctic environment, although mostly in areas that are less politically challenging, or in non-binding form. It has developed

78 'Northern Dimension' at https://eeas.europa.eu/diplomatic-network/northern-dimen sion/347/northern-dimension_en; accessed 5 September 2017.

79 See L-M van der Watt, A Riedel, B Dahlbäck, E Tedsen, K Jagodziński and P Kankaanpää, 'European Arctic Initiatives: Capacities, Gaps and Future Opportunities' in Stępień, Koivurova and Kankaanpää (eds.), (n 15) 243-295. Convention on Future Multilateral Cooperation in the North-East Atlantic Fisheries (NEAFC). Adopted 18 November 1980, London; in force 17 March 1982, 1285 UNTS 129.

An integrated European Union policy for the Arctic (n 20). 
an Agreement on Cooperation on Marine Oil Pollution, Preparedness and Response in the Arctic, ${ }^{81}$ as well as the Arctic Offshore Oil and Gas Guidelines. ${ }^{82}$ It has also recognized ecosystem-based management as important for sustainable development in the Arctic.

Also beyond the Arctic Council there are significant processes ongoing which aim to protect either the Arctic environment specifically, or which could be important in that regard even though they have a broader aim. These include the initiation in 2016 of negotiations of an agreement that would prevent the opening up of unregulated fisheries in the Central Arctic Ocean, ${ }^{83}$ and the 2015 decision by the UN General Assembly to develop an international legally binding instrument under the LOSC on the conservation and sustainable use of marine biological diversity of areas beyond national jurisdiction. ${ }^{84}$ In both processes the EU plays a role. ${ }^{85}$

These initiatives, even if successfully completed, are a far cry from a comprehensive and integrated system for MSP in the Arctic. However, to aim for a multilateral regime concerning MSP for the Arctic is not very realistic in the foreseeable future, considering the strong opposition even within the EU itself to any more far-reaching obligations pertaining to joint planning of ocean space. Chances are also that such an agreement, if accomplished, would be so lacking in substance that it would rather risk justifying the continuation of unsustainable practices.

81 Kiruna, 15 May 2013, not yet in force. Available at http://www.arctic-council.org/eppr/ agreement-on-cooperation-on-marine-oil-pollution-preparedness-and-response-in-the -arctic; accessed 23 June 2017.

82 Available at https://oaarchive.arctic-council.org/handle/11374/63; accessed 23 August 2017 .

83 'The EU engages in the third round of negotiations to prevent unregulated fishing in the Arctic high seas, 02/12/2016' available at https://ec.europa.eu/maritimeaffairs/content/ eu-engages-third-round-negotiations-prevent-unregulated-fishing-arctic-high-seas_en; accessed 22 August 2017.

84 UNGA Resolution 69/292, Development of an international legally binding instrument under the United Nations Convention on the Law of the Sea on the conservation and sustainable use of marine biological diversity of areas beyond national jurisdiction (6 July 2015) A/RES/69/292.

85 The EU engages in negotiations ( $n$ 83); Marine biodiversity in areas beyond national jurisdiction: international community marks a step forward, 13 September 2016. Available at https://ec.europa.eu/maritimeaffairs/content/marine-biodiversity-areas-beyond -national-jurisdiction-international-community-marks-step_en; accessed 20 December 2016. 
A network-based approach to MSP in the Arctic, not building exclusively on initiatives by national governments, but also recognizing leadership by other actors, such as indigenous peoples, has been proposed..$^{86}$ In such a context the EU may find many ways to contribute and influence, without purporting to occupy the high ground, through the different actors and processes that the EU comprises and in which it participates. But that is likely to require concerted action in line with the Arctic policy and also the further development and concretization of that policy. At the end of the day, it may also be wise for the EU to recognize that its status as an Arctic actor is likely always to be qualified by geographical factors, unless, that is, a country like Iceland were to join the EU.

86 C Ehler, Marine Spatial Planning in the Arctic: a first step toward ecosystem-based management, A report of the Aspen Institute's Dialogue and Commission on Arctic Climate Change (The Aspen Institute, Washington, DC, 2011) 40-82, at p. 79. 